\begin{tabular}{|c|c|c|}
\hline \hline & International Journal of Current Research in \\
\hline & Biosciences and Plant Biology \\
\hline EXCELLENT \\
PUBLISHERS
\end{tabular}

\title{
Comparison of four seaweed extracts on germination and root promotion of Lens esculenta
}

\section{Lucia Teresa Mendoza-Morales',2, Angela Catalina Mendoza-González², Luz Elena Mateo Cid² and Angélica Rodríguez-Dorantes ${ }^{*}$}

\author{
${ }^{1}$ Laboratorio de Fisiología Vegetal, Departamento de Botánica, Escuela Nacional de Ciencias Biológicas, \\ Instituto Politécnico Nacional, México City 11340, México \\ ${ }^{2}$ Laboratorio de Ficología, Departamento de Botánica, Escuela Nacional de Ciencias Biológicas, \\ Instituto Politécnico Nacional, México City 11340, México \\ ${ }^{*}$ Corresponding author; e-mail: rodorantes@yahoo.com.mx; Tel.: +55-557-29-63-oo, Ext. 62332
}

\begin{tabular}{|c|c|}
\hline Article Info & ABSTRACT \\
\hline $\begin{array}{l}\text { Date of Acceptance: } \\
20 \text { April } 2019\end{array}$ & \multirow{3}{*}{$\begin{array}{l}\text { Biostimulants were considered as biological, organic and synthetic components that } \\
\text { promote the plant growth; recently seaweed extracts have been reported as plant } \\
\text { biostimulants applied to agricultural systems and there were reported positive effects of } \\
\text { them on germination and root promotion. The aim of the present work was to analyze } \\
\text { and compare the effect of four seaweed extracts from Gracilaria debilis, Sargassum } \\
\text { liebmanni, Sargassum vulgare and Ulva fasciata on germination and root elongation } \\
\text { of Lens esculenta. The plant root elongation promoting (PREP) activity assay was } \\
\text { employed to analyze the effect of seaweed liquid extracts on Lens esculenta seeds by a } \\
\text { tolerance index, the normalized residual percentage of germinated seeds index and the } \\
\text { normalized residual elongation root index. Even there was a toxic effect of the extracts } \\
\text { from two of the seaweeds tested: } S \text {. vulgare and U. fasciata on L. esculento } \\
\text { germination; all the seaweed liquid extracts showed a good response at low } \\
\text { concentrations; particularly the employ of } S \text {. liebmannii and U. fasciata are } \\
\text { recommended at a moderate dilution rate of their extracts for the increase of } \\
\text { germination and growth of plants tested. }\end{array}$} \\
\hline Keywords & \\
\hline $\begin{array}{l}\text { Biostimulants } \\
\text { Lens esculenta } \\
\text { Liquid seaweed extracts }\end{array}$ & \\
\hline
\end{tabular}

\section{Introduction}

Biostimulants were considered as biological, organic and synthetic components that promote the plant growth (Sangha et al., 2014); particularly, seaweed mulch or extracts have recently reported as plant biostimulants applied to agricultural systems (Zhang and Schmidt, 1997; Khan etal., 2009; Craigie, 2011; Spann and Little, 2011). Various industrial-scale and commercial processes have been developed and management as liquid extracts and powders from a wide range of seaweeds such as Ascophyllum nodosum, Fucus spp., Laminaria spp., Sargassum spp., Ecklonia maxima, and Durvillaea spp. (Hong et al., 2007). Some authors have reported that natural seaweeds are used as substitute of synthetic fertilizers; because they contain multiple growth regulators (Begum et al., 2018); such as cytokinins (Durand et al., 2003), auxins (Sahoo, 2000; Stirk et al., 2004), 
gibberellins (Wildgoose et al. 1978; Strik and Staden, 1997) and various macro and micronutrients necessary for plant growth and development (Khan et al., 2009). There were some reports regarding to positive effects of seaweed extracts on germination; specially some of them have reported higher germination percentage with low concentration of the extracts. Pramanick et al. (2014) andLayek et al. (2018) reported that when rice seeds were soaked in lower concentrations of seaweed extracts recorded higher germination percentage. Similar results were reported in case of maize plants, when seeds were soaked in $5 \%$ concentration of extracts from Kappaphycus sp. and Gracilaria sp. showing a higher rate of germination; while $15 \%$ concentration inhibited the germination (Layek et al., 2016). Higher germination percentage was also reported in Vigna radiata (Venkataraman and Mohan, 1997) and Vigna sinensis (Sivasankari et al., 2006). Plants treated with seaweed extracts have been reported to show a deep root development by improving lateral root formation (Atzmon and van Staden, 1994) and increased the total volume of the root system (Slàvik, 2005). The aim of the present work was to analyze and compare the effect of four seaweed extracts on germination and root elongation of Lens esculenta.

\section{Materials and methods}

\section{Preparation of seaweed liquid extracts}

For this study, the seaweeds Sargassum vulgare and Ulva fasciata were hand collected from the intertidal zone at one meter of deep, in "El pulpo beach" located in Barra de Cazones, from Cazones de Herrera municipality in Veracruz, México; Gracilaria debilis was hand collected from the intertidal zone at one meter of deep, in Villamar, Campeche, México and Sargassum liebmannii was were hand collected from the intertidal zone at one meter of deep, in Los Tronconos, Guerrero, México. Collected seaweeds were cleaned several times with sea water to remove sand, other impurities and epiphytes, then transported to the laboratory and again cleaned four times with tap water and finally shade dried. These shade-dried seaweeds were finely chopped and powdered with a Nutribullet $\AA$. The aqueous extracts were obtained according to Mendoza et al. (2019), as follows: seaweed powders were filtered through metallic mesh number $16(1 \mathrm{~mm})$ and $25 \mathrm{~g}$ of each were deposited in flasks filled with $300 \mathrm{~mL}$ of distilled water and boiled at $80^{\circ} \mathrm{C}$ for $45 \mathrm{~min}$ in a water bath. Then the extracts were allowed to cool at room temperature and filtered through medium pore filter paper. Finally, the filtrates were considered as $100 \%$ of seaweed liquid extracts (SLE) and stored at $4^{\circ} \mathrm{C}$ for the bioassays.

\section{Effect of seaweed extracts on Lens esculenta seeds by the plant root elongation promoting (PREP) activity assay}

The plant root elongation promoting (PREP) activity assay (Belimov et al., 2005) was employed to analyze the effect of seaweed liquid extracts on Lens esculenta seeds. Commercially seeds of Lens esculenta were surface-sterilized with $10 \%$ sodium hypochlorite solution for 3 minutes and rinsed with deionized sterile water. Fifteen seeds were placed in Petri dishes with sterile filter paper; $7 \mathrm{~mL}$ of the different concentrations of each SLE: 5,10 , 20 and $30 \%$ prepared by diluting the concentrate extracts with sterile distilled water, were added and $7 \mathrm{~mL}$ of sterile distilled water was considered as control. All the experiments were performed by triplicate and maintained in a growth chamber incubated in dark at $28^{\circ} \mathrm{C}$ for 5 days. After this period, seeds germinated were counting and seedlings were obtained and photographed. The root length of each plant was measured employing the EZ-Rhizo II (Ver. 2.4.5.10) program.

The analysis of the effect of seaweed extracts were done measuring the germination percentage and root length of $L$. esculenta seedlings after their incubation; tolerance index (TI) was obtained as the ratio of the root lengths of seedlings grown in the presence and absence of the specific added seaweed extract (Wilkins, 1978; Burd et al., 1998); $\mathrm{TI}=$ RLse / RLc where RLse is the root length of plants grown in the presence of a specific added seaweed extract and RLc is the root length of plants grown in absence of seaweed extract (control). Also the toxicity of experimental conditions to $L$. esculenta, was measured according to BagurGonzález et al. (2011), by the Normalized Residual Percentage of Germinated Seeds Index (NRPGI) following the equation: NRPGI = Gexp-Gc/Gc Where, Gexp is the \% average of germinated seeds in experimental conditions tested (each seaweed extracts at 5, 10, 20 and 30\%), and Gc is the \% 
average of germinated seeds in control condition and by the Normalized Residual Elongation Root Index (NRERI) following the equation: NRERI = REexp-REc/REc Where, REexp is the average length of the root seedlings in experimental conditions tested and REc is the average length of the root seedlings in control condition. BagurGonzález et al. (2011) noted that the employ of these indices allows the analysis in this study of the toxicity produced by the SLE tested; with values between -1 (maximum phytotoxicity) to $>0$, in a scale proposed by these authors that gives a good classification of this effect: A values $=0$ to -0.25 (low toxicity), B values $=-0.25$ to -0.5 (moderate toxicity), $\mathrm{C}$ values $=-0.5$ to -0.75 (high toxicity) and $\mathrm{D}$ values $=-0.75$ to -1 (very high toxicity); values $>$ $\mathrm{o}$ indicated a stimulation of growth determined as hormesis effect.

\section{Statistical analysis}

All data obtained were analyzed by one-way analysis of variance and the mean differences were compared applying a Tukey-Kramer Method using the statistics program Graph Pad Instat Ver. 2.03. A numerical comparative analysis considering the experimental conditions; a distance matrix was built using the conventional standard distance coefficient, a phenogram was build using the unweighted pair group method of arithmetic averages (UPGMA) method and correlation coefficient of Pearson was obtained using the NTSyS-PC version 2.11T (Numerical Taxonomy and Multivariate Analysis System) software.

\section{Results and discussion}

\section{Effect of seaweed extracts on Lens esculenta germination and root promotion}

Fig. 1 shows the L. esculenta seedlings comparing all the seaweed extracts tested in each Petri dish bioassays. Fig. 2 shows the particularly details about the roots growth in each experimental conditions. Germination percentage of L. esculenta seeds, showed a particularly positive effect of $S$. liebmannii and G. debilis with 100\%; while this percentage reduced in seeds exposed to $U$. fasciata as follows: $100>83>17>16 \%$ with $5,10,20$ and $30 \%$ extract concentrations and seeds exposed to $S$. vulgare liquid extracts: $51>49>44>40$ with 20, 5, 10 and 30\% concentrations. Fig. 3 presented the root length obtained in all the experimental SLE concentrations tested; according to the obtained results, the comparison between the root lengths in each particular condition showed that even all the seaweed extracts promote the root elongation bellow the control response of roots; the best elongation response was obtained in the next order: $U$. fasciata $>S$. liebmannii $>S$. vulgare $>G$. delins.

\section{Phytotoxicity of seaweed extracts tested regarding to germination and root response of $L$. esculenta}

The response against the seaweeds extracts, was determined by the RTI (Table 1), against SLE where experiments with $S$. liebmanii extracts showed the highest values of roots tolerance: 0.73 , $0.97,0.67$ and 0.85 to $5,10,20$ and $30 \%$, respectively; followed by $U$. fasciata extract with TI values: $0.67,0.73$ and 0.58 for 5,10 and $20 \%$, respectively. Almost the same root inhibitory response was obtained between all the concentrations tested of liquid extracts from $S$. vulgare and $G$. debilis, where no particular differences between them were obtained (o.33 to 0.50). As Corona et al. (2018) reported the results of these experiments presented as tolerance index are important according also to Burd et al. (1998); where a TI value of 1.0 indicates that the experiment condition was not inhibitory, whereas a value of 0.1 indicates this was only $10 \%$ of the growth of control seedlings.

Regarding to the possible toxic effect of seaweeds extracts on L. esculenta, the analysis done of the phytotoxic effect by the determination of the NRPGI and NRERI indices according to BagurGonzález et al. (2011) (Table 2), showed that experiments that affect seed germination were grouped in four categories: "A" (low toxicity): $G$. debilis and $S$. liebmannii at all the concentrations tested, $U$. fasciata at 5 and $10 \%$ and $S$. vulgare at 20\%; "B" (moderate toxicity):S. vulgare at 5\%;"C category" (high toxicity): S. vulgare at 10 and 30\%; and "D" (very high toxicity): U. fasciata at 20 and $30 \%$. Regarding to the effect on seed germination, no toxicity at all was founded and the SLE concentrations tested for $S$. liebmannii and $G$. debilis promotes the $100 \%$ of germination. For $S$. vulgare and $U$. fasciata SLE concentrations of 20 and $10 \%$ respectively promotes the germination of 
L. esculenta agree with the results reported by Kumar and Sahoo (2011), whose noted that the application of Sargassum wightii seaweed liquid extract increases the seed germination percentage of Triticum aestivum var. Pusa Gold. Seeds treated with $20 \%$ seaweed extract gave highest percentage of germination. Xavier and Jesudass (2007) also reported that $100 \%$ seed germination was found in lower concentrations of Caulerpa recemosa extract. Jothinayagi and Anbazhagan (2009) also reported the effect of different concentrations of SLE of Sargassum wightii on germination percentage of Abelmoschus esculentus; where seeds germination (100\%) was found at $20 \%$ concentration. A. esculentus seeds soaked with lower concentrations of the $S$. wightii extracts showed higher rates of germination, while the higher concentrations of the extracts inhibited the germination. Sivasankari et al. (2006) analyzed the effect of liquid extracts from Sargassum wightii and Caulerpa chemnitzia on germination percentage of Vigna sinensis; for both seaweeds, greatest seed germination (100 and 98\%, respectively) was found at $20 \%$ concentration in SLE soaked seeds. Challen and Hemingway (1965) noted that the increase of germination percentage at low concentrations may be due to the presence of some growth promoting substances (such as auxins, gibberellins and cytokinins), micronutrients, vitamins and amino acids.
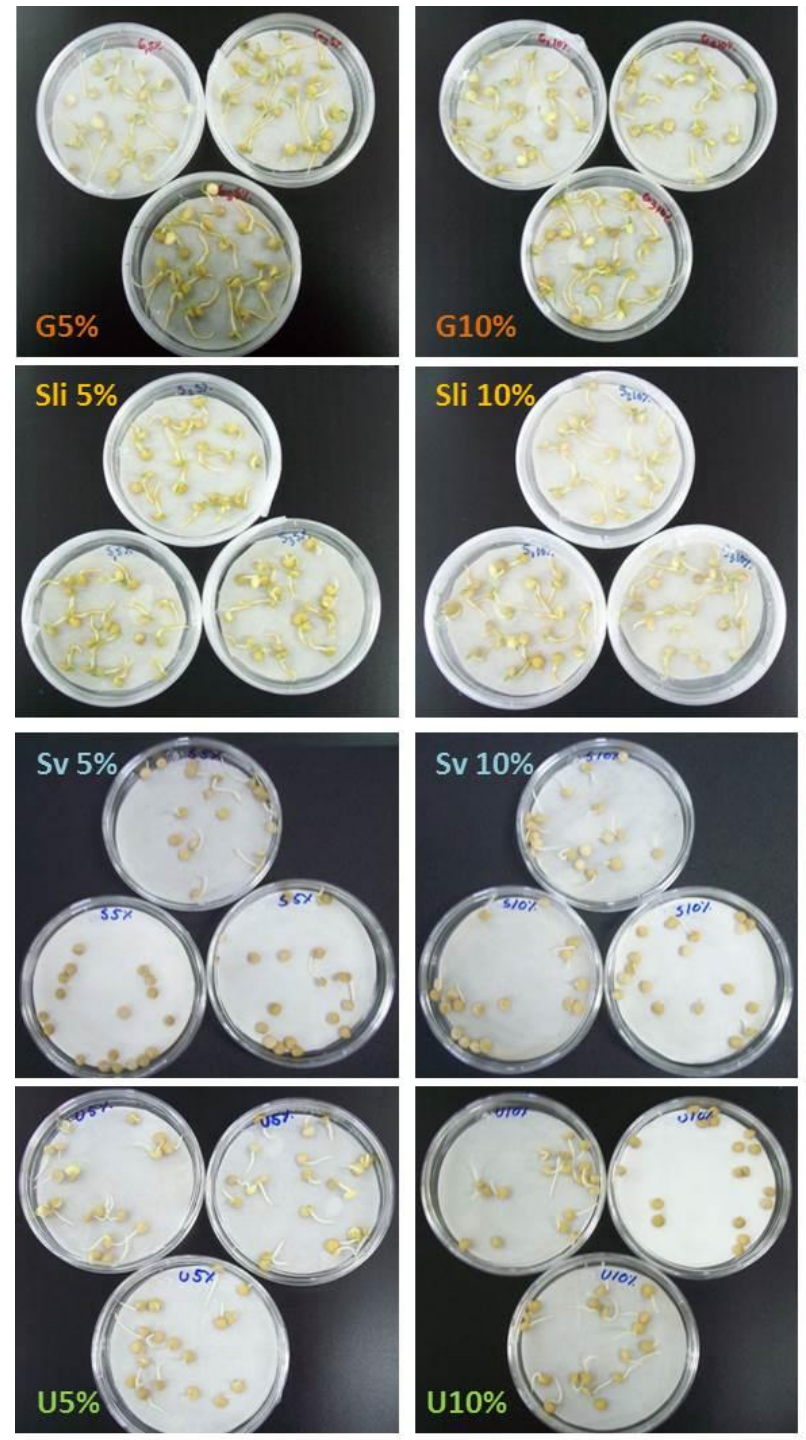
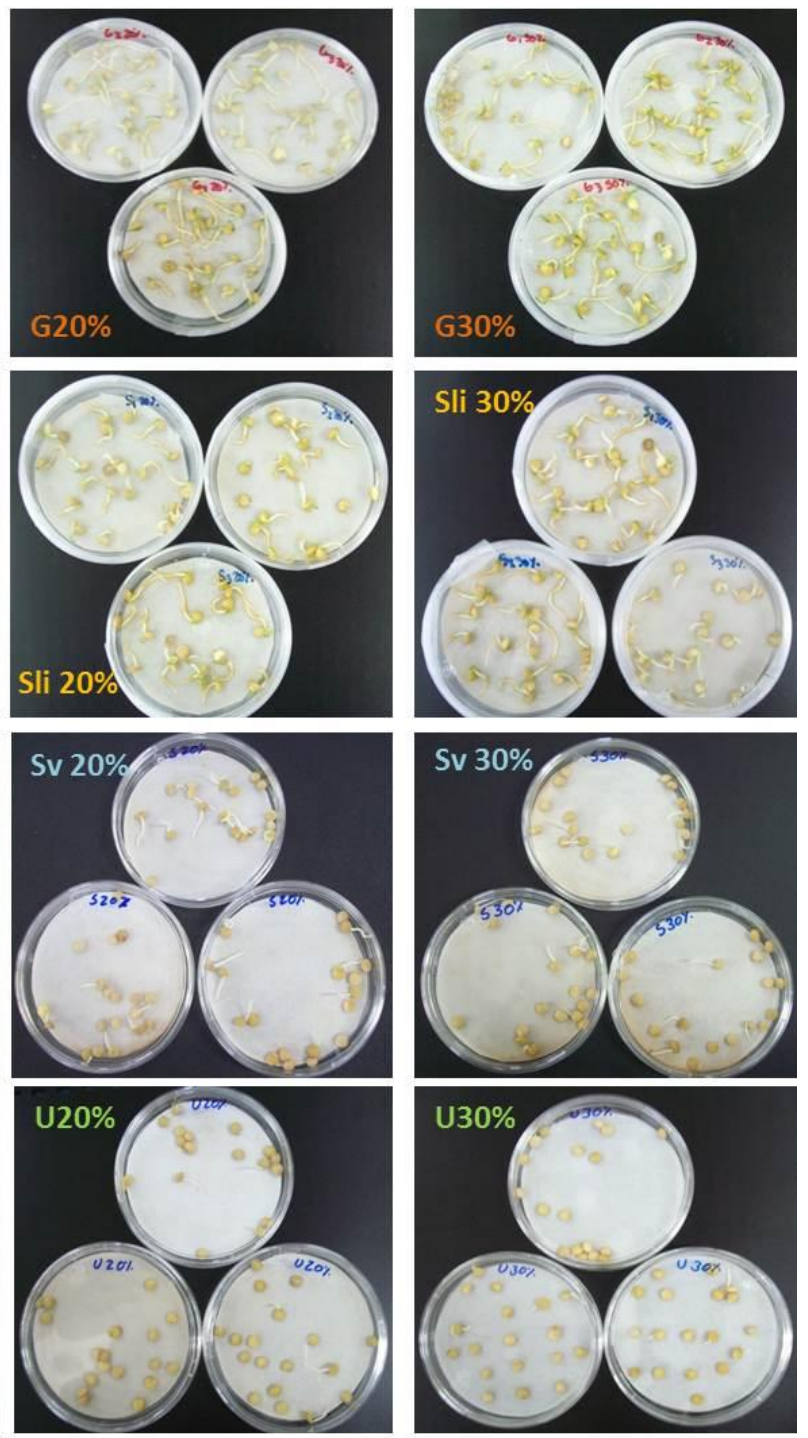

Fig. 1: Lens esculenta seedlings exposed to the four seaweed extracts: G: Gracilaria debilis, Sli: Sargassum liebmannii, Sv: Sargassum vulgare and U: Ulva fasciata. 

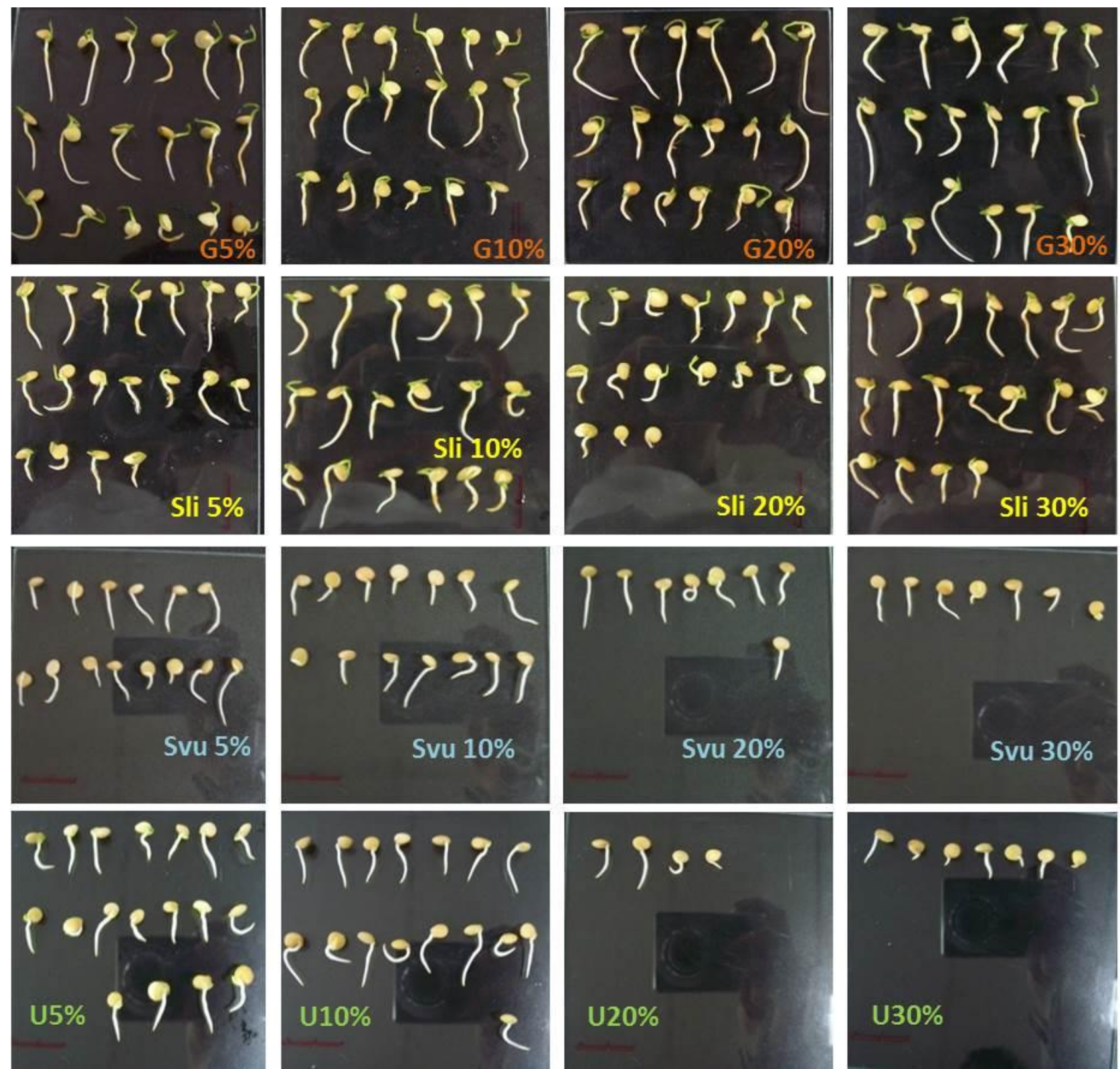

Fig. 2: Lens esculenta root development under the four seaweed extracts: G: Gracilaria debilis, Sli: Sargassum liebmannii, Sv: Sargassum vulgare and U: Ulva fasciata.

The germination percentage increased with concentration levels upto $20 \%$ and there after it declined. No germination was found at $50 \%$ and above. The lowest germination percentage (65\%) was found at $40 \%$ extract of $C$. chemnitzia treated water soaked seeds. Similar results were obtained for L. esculenta treated with $U$. fasciata $30 \%$ liquid extract, classified as a very toxic seaweed extract.

Experiments that influenced root length were characterized according to "A category" (low toxicity): S. liebmannii only at 10 and $30 \%$; "B category" (moderate toxicity): $S$. liebmannii only at 5 and $20 \%, U$. fasciata at 5,10 and $20 \%$ and $S$. vulgare at 20\%; and "C category" (high toxicity): $G$. debilis at all the concentrations tested, $S$. vulgare at 5,10 and $30 \%$ and U. fasciata at $30 \%$. Regarding to root elongation, Sargassum species tested showed that all $S$. liebmannii SLE concentrations tested and particularly the SLE $S$. vulgare $20 \%$ concentration, promoted the root response. Even $U$. fasciata showed moderate toxicity for all its LSE concentrations tested; there was a promotion of root length at 5,10 and $20 \%$. 
Table 1. Determination of Tolerance Index of Lens esculenta.

\begin{tabular}{c|c}
\hline SLE (\%) & Root Tolerance Index \\
\hline \multicolumn{2}{c}{ Sargassum liebmanni } \\
\hline $\mathbf{5}$ & 0.737 \\
$\mathbf{1 0}$ & 0.977 \\
$\mathbf{2 0}$ & 0.676 \\
$\mathbf{3 0}$ & 0.858 \\
\hline \multicolumn{2}{|c}{ Sargassum vulgare } \\
\hline $\mathbf{5}$ & 0.471 \\
$\mathbf{1 0}$ & 0.484 \\
$\mathbf{2 0}$ & 0.501 \\
$\mathbf{3 0}$ & 0.43 \\
\hline \multicolumn{2}{|c}{ Gracilaria debilis } \\
\hline $\mathbf{5}$ & 0.417 \\
$\mathbf{1 0}$ & 0.326 \\
$\mathbf{2 0}$ & 0.479 \\
$\mathbf{3 0}$ & 0.339 \\
\hline \multicolumn{3}{|c}{ Ulva fasciata } \\
\hline $\mathbf{5}$ & 0.676 \\
$\mathbf{1 0}$ & 0.732 \\
$\mathbf{2 0}$ & 0.589 \\
$\mathbf{3 0}$ & 0.351 \\
\hline \multicolumn{2}{|c}{} \\
\hline
\end{tabular}

\section{Relationship between experimental conditions and $L$. esculenta response}

Finally, according to the multivariate analysis that consider germination percentage, root length and root tolerance index as parameters; Fig.4shows the association of groups according with the nature of the responses obtained for each experimental condition; where two groups forming at first: group Ia made only by the 10\% LSE from $U$. fasciata and group Ib by all the SLE concentrations from $S$. liebmanni and $G$. debilis and SLE of $5 \%$ from $U$. fasciata; the rest of them comprise the group II; in this group the control $L$. esculenta response and LSE concentrations 20 and $30 \%$ from $U$. fasciata form the group IIa and the other conditions forming the group IIb by all SLE concentrations from $S$. vulgare.

This analysis demonstrate that there were some particularly relationships between $S$. vulgare and $U$. fasciata from SLE of 20 and $30 \%$ concentrations that were similar and the other seaweeds tested also showed a particular association between $G$. debilis and S. liebmanni as more closer groups.

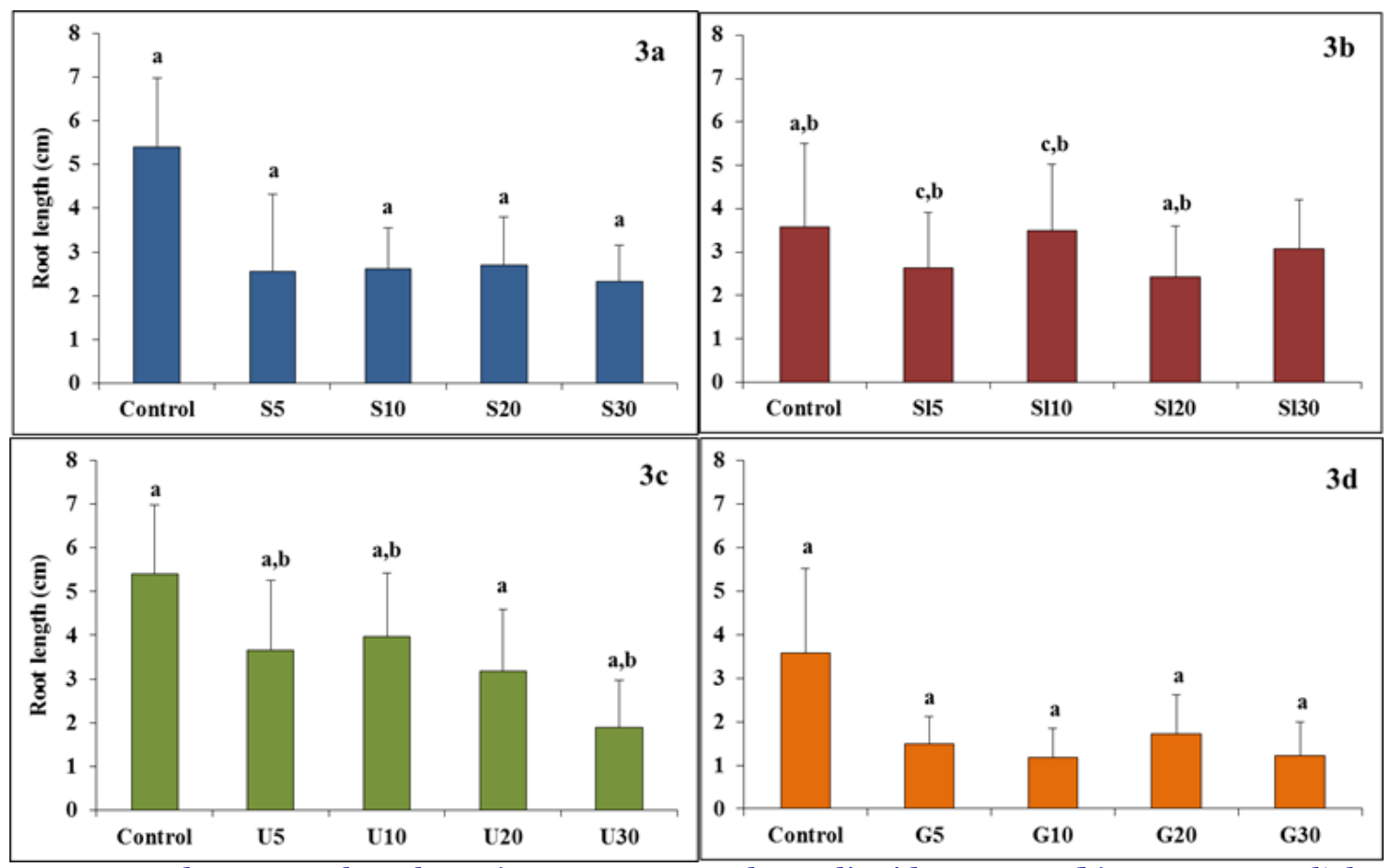

Fig.3. Lens esculenta root length: 3a) Sargassum vulgare liquid extract, 3b) Sargassum liebmannii liquid extract, 3c) Ulva fasciata liquid extract and 3d) Gracilaria debilis liquid extract. [ $\mathrm{n}=15$. Mean values \pm S.D. from triplicates are given. The different lower-case letters shows the significant differences founded $(\mathrm{a}=\mathrm{p}<0.001, \mathrm{~b}=\mathrm{p}<0.01, \mathrm{c}=\mathrm{p}<0.05)]$. 
Table 2. Determination of NRERI and NRPGI indices of Lens esculenta seedlings.

\begin{tabular}{|c|c|c|c|c|}
\hline \multicolumn{5}{|c|}{ NRERI index } \\
\hline SLE (\%) & Sargassum liebannii & Sargassum vulgare & Gracilaria debilis & Ulva fasciata \\
\hline 5 & B, -0.2625 & $C,-0.5284$ & $C,-\mathbf{- 0 . 5 8 2 1}$ & $\mathrm{B}, \mathbf{- 0 . 3 2 3 5}$ \\
\hline 10 & A, $-\mathbf{0 . 0 2 2 3}$ & C, $-\mathbf{- 0 . 5 1 5 7}$ & $C,-\mathbf{0 . 6 7 3 5}$ & B, $-\mathbf{- 0 . 2 6 7 3}$ \\
\hline 20 & B, -0.3234 & B, - 0.4984 & C, $-\mathbf{- 0 . 5 2 0 8}$ & B, -0.4106 \\
\hline 30 & A, $-\mathbf{0 . 1 4 1 8}$ & C, $-\mathbf{- 0 . 5 6 9 7}$ & C, $-\mathbf{- 0 . 6 6 0 9}$ & C, $-\mathbf{- 0 . 6 4 8 8}$ \\
\hline \multicolumn{5}{|c|}{ NRPGI index } \\
\hline SLE (\%) & Sargassum liebannii & Sargassum vulgare & Gracilaria debilis & Ulva fasciata \\
\hline 5 & A, 0 & B, - -0.50005 & A, 0 & A, 0 \\
\hline 10 & $\mathrm{~A}, \mathbf{0}$ & C, $-\mathbf{- 0 . 5 5 5 6}$ & A, 0 & A, $-\mathbf{0 . 1 6 6 8}$ \\
\hline 20 & A, 0 & A, $-\mathbf{- 0 . 1 8 6 7}$ & A, 0 & $D,-\mathbf{0 . 8 2 2 3}$ \\
\hline 30 & $\mathrm{~A}, \boldsymbol{0}$ & C, $-\mathbf{0 . 5 9 2 7}$ & $\mathbf{A}, 0$ & D, -0.8397 \\
\hline
\end{tabular}

*Where: $\mathbf{A}=0$ a -0.25 low toxicity, $\mathbf{B}=-0.25$ a -0.5 moderate toxicity, $\mathbf{C}=-0.5$ a -0.75 high toxicity, $\mathbf{D}=-0.75$ a -1.0 very high toxicity y $\mathbf{E}=>0$ hormesis (Bagur-González et al., 2011).

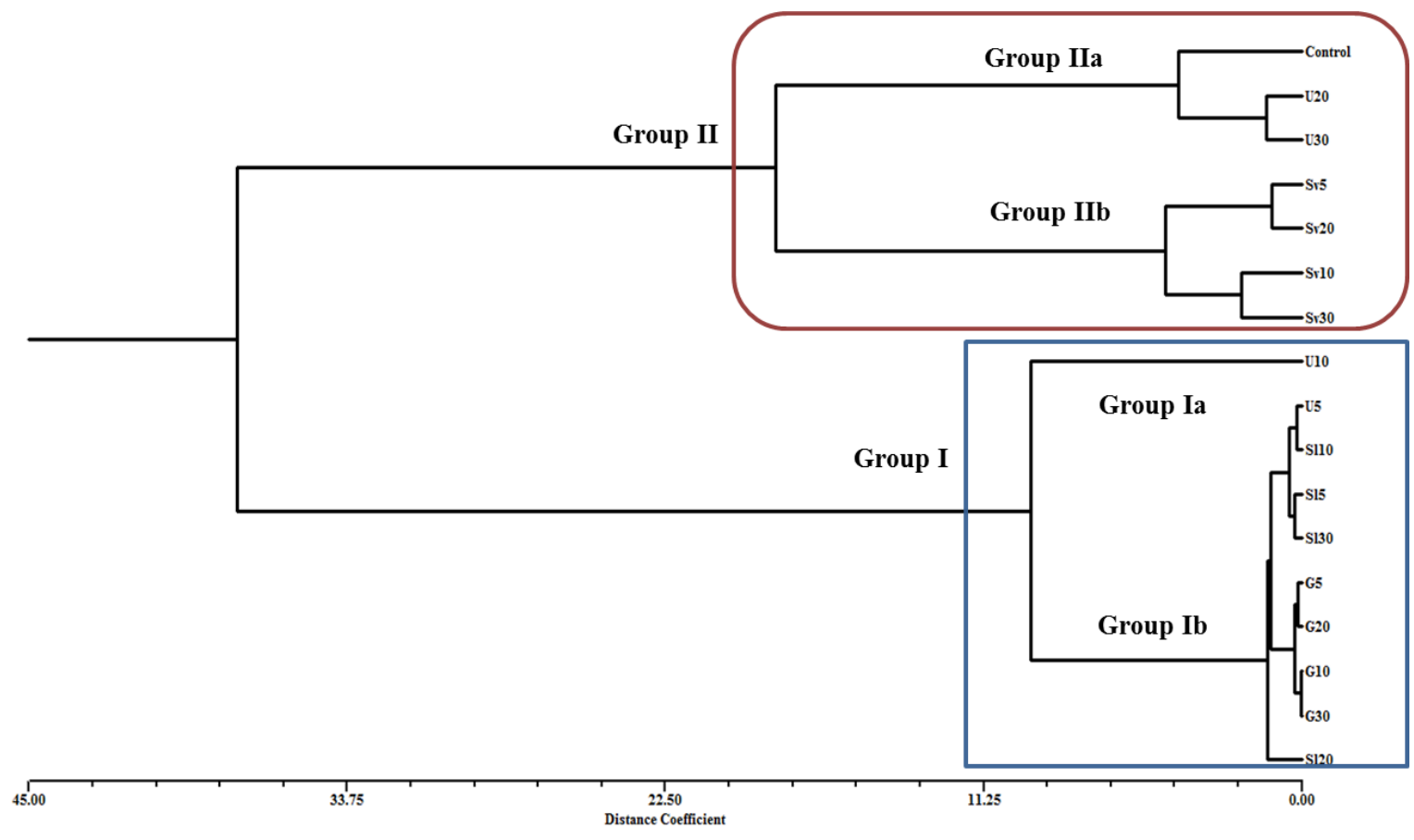

Fig. 4: Phenogram comparing the experimental conditions tested $(r=0.91)$.

\section{Conclusion}

This work showed the particularly effect of four seaweed extracts tested from Gracilaria debilis, Sargassum liebmanni, Sargassum vulgare and Ulva fasciata on germination and root length response of Lens esculenta, where even there was a toxic effect of the extracts from two of the seaweeds tested: $U$. fasciata and $S$. vulgare on $L$. esculenta germination; all the seaweed liquid extracts showed a good response at low concentrations; particularly the employ of $S$. liebmannii and $U$. fasciata are recommended at moderate dilution rate of their extracts for the increase of germination and growth of plants tested.

\section{Conflict of interest statement}

Authors declare that they have no conflict of interest.

\section{Acknowledgement}

Authors are grateful to the Research Projects SIPIPN: 20181504 and SIP-IPN:20195117 of the 
Secretaría de Investigación y Posgrado del Instituto Politécnico Nacional, for providing the facilities to carry out this work and also wish to thank for the fellowshipsfrom Comision de Operación y Fomento de Actividades Académicas (COFAA, I.P.N.), EDI (Estímulo al Desempeño de los Investigadores, I.P.N.) and SNI-CONACYT.

\section{References}

Atzmon, N., van Staden, J., 1994. The effect of seaweed concentrate on the growth of Pinus pinea seedlings. New For. 8, 279-288.B

Bagur-González, M.G., Estepa-Molina, C., MartínPeinado, F., Morales-Ruano, S., 2011. Toxicity assessment using Lactuca sativa L. bioassay of the metal (loid)s $\mathrm{As}, \mathrm{Cu}, \mathrm{Mn}, \mathrm{Pb}$ and $\mathrm{Zn}$ in soluble-in-water saturated soil extracts from an abandoned mining site. J. Soils Sediments. 11, 281-289.

Begum, M. Bordoloi, B.Ch., Singha, D.D., Ojha, N.J., 2018. Role of seaweed extract on growth, yield and quality of some agricultural crops: a review. Agricult. Rev. 39, 321-326.

Belimov, A.A., Hontzeas, N., Safronova, V.I, Demchinskaya, S.V., Piluzza, G., Bullitta, S., Glick, B.R., 2005. Cadmium-tolerant plant growth-promoting bacteria associated with the roots of Indian mustard (Brassica juncea L. Czern.). Soil Biol. Biochem. 37, 241-250.

Burd, G.I., Dixon, D.G., Glick, B.R., 1998. A plant growth-promoting bacterium that decreases nickel toxicity in seedlings. Appl. Environ. Microbiol. 64, 3663-3668.

Challen, S.B., Hemingway, J.C., 1965. Growth of higher plants in response to feeding with seaweed extracts. Proc. Int. Seaweed Symp. 5, 359-367.

Corona-Álvarez, D., Guerrero-Zúñiga, L.A., Rodríguez-Dorantes, A., 2018. Comparison in growth parameters of the bacterization effect on Axonopus affinis seeds and EDTA against cadmium. Int. J. Curr. Res. Biosci. Plant Biol. 5, 25-34.

Craigie, J.S., 2011. Seaweed extracts stimuli in plant science and agriculture. J. Appl. Phycol. 23, 371-393.

Durand,N., Brian.X.,Meyer.C., 2003. The effect of marine bioactive substances (N PRO) and edogenous cytokinins on nitrate reductase activity in Arabidopsis thaliana. Physiol. Plant. 119, 489-493.
Hong, D., Hien, H., Son, P., 2007. Seaweeds from Vietnam used for functional food, medicine and biofertilizer. J. Appl. Phycol. 19, 817-826.

Jothinayagi, N., Anbazhagan, C., 2009. Effect of seaweed liquid fertilizer of Sargassum wightii on the growth and biochemical characteristics of Abelmoschus esculentus (L.) Medikus. Recent Res. Sci. Technol. 1, 155-158.

Khan, W., Rayirath, U.P., Subramanian, S., Jithesh, M.N., Rayorath, P., Hodges, D.M., Critchley, A.T., Craigie, J.S., Norrie, J., Prithiviraj, B., 2009. Seaweed extracts as biostimulants of plant growth and development. Plant Growth Regul. 28, 386399.

Kumar, G., Sahoo, D., 2011. Effect of seaweed liquid extract on growth and yield of Triticum aestivum var. Pusa Gold. J. Appl. Phycol. 23, 251-255.

Layek, J., Das, A., Ramkushna, G.I., Ghosh, A., Panwar, A.S., Krishnappa, R., Ngachan, N.V., 2016. Effect of seaweed sap on germination, growth and productivity of maize (Zea mays) in North Eastern Himalayas. Indian J. Agron. 61, 354-359.

Layek, J., Das.A., Ramkrushna, G.I., Sarkar. D., Ghosh, A., Zodape, S.T., Lal,R., Yadav, G.S., Panwar, A.S., Ngachan, S., Meena, R.S., 2018. Seaweed extract as organic bio-stimulant improves productivity and quality of rice in eastern Himalayas. J. Appl. Phycol. 30, 547558.

Layek, J., Ramkrushna, G.I., Das, A., Ghosh, A., Krishnappa, R., Panwar, A.S., Azad Thakur, N.S., Ngachan, S.V., Zodape, S.T.,Buragohain, J., Mawlong, B., 2014. Seaweed sap as organic iostimulant for rice and maize production. Research BulletinNo.82. ICAR Research Complex for NEH region, Umiam, Meghalaya, India.

Mendoza-Morales, L.T., Mendoza-González, A.C., Mateo- Cid, L.E., Rodríguez-Dorantes, A., 2019. Effect of seaweed liquid extracts on the internode variation of Lens esculenta seedlings. Int. J. Sci. 8, 1-5.

Pramanick, B., Brahmachari, K., Ghosh, A., 2014. Efficacy of Kappaphycus and Gracilaria sap on growth and yield improvement of sesame in new alluvial soil. J. Crop Weed. 10, 77-81.

Sahoo, D., 2000. Farming the ocean. In: Seaweeds Cultivation and Utilization. Aravali Books International. New Delhi, India, 40. 
Sangha, J.S., Kelloway, S., Critchley, A.T., Prithiviraj, B., 2014. Seaweeds (Macroalgae) and their extracts as contributors of plant productivity and quality: the current status of our understanding. Adv. Bot. Res. 71, 189-219.

Sivasankari, S., Venkatesalu, V., Anantharaj, M., Chandrasekaran, M., 2006. Effect of seaweed extracts on the growth and biochemical constituents of Vigna sinensis. Bioresour. Technol. 97, 1745-1751.

Slàvik, M., 2005. Production of Norway spruce (Picea abies) seedlings on substrate mixes using growth stimulants. J. For. Sci. 51, 15-23.

Spann, T.M., Little, H.A., 2011. Applications of a commercial extract of the brown seaweed Ascophyllum nodosum increases drought tolerance in container-grown 'Hamlin' sweet orange nursery trees. HortSci. 46, 577-582.

Stirk, W.A., Arthur, G.D., Lourens, A.F., Novak, O., Strnad, M., van Staden, J., 2004. Changes in cytokinin and auxin concentrations in seaweed concentrates when stored at an elevated temperature. J. Appl. Phycol. 16, 31-39.
Strik, W., Staden, V.J., 1997. Isolation and identification of cytokinins in a new commercial seaweed product made from Fucus serratus L. J. App. Phycol. 9, 327-330.

Venkataraman, K.V., Mohan, V.R., 1997. Effect of seaweed extract $\mathrm{SM}_{3}$ on the cyanobacterium, Scytonema species. Seaweed Res. Utiln. 19, 1315 .

Wildgoose, P.B., Blunden, G., Jewers, K.,1978. Seasonal variation in gibberellin activity of some species of Fucaceae and Laminariaceae. Bot. Mar. 21, 63-65.

Wilkins, D.A., 1978. The measurement of tolerance to edaphic factors by means of root growth. New. Phytol. 80, 623-633.

Xavier, G.S.A., Jesudass, L.L., 2007. Effect of seaweed extracts on cluster bean. Seaweed Res. Util. 29, 85-87.

Zhang, X., Schmidt, R., 1997. The impact of growth regulators on the a-tocopherol status in waterstressed Poa pratensis. Int. Turfgrass Soc. Res. J. 8, 1364-1371.

\section{How to cite this article:}

Mendoza-Morales, L. T., Mendoza-González, A. C., Mateo Cid, L. E., Rodríguez-Dorantes, A., 2019. Comparison of four seaweed extracts on germination and root promotion of Lens esculenta. Int. J. Curr. Res. Biosci. Plant Biol. 6(5), 1-9. doi: https://doi.org/10.20546/ijcrbp.2019.605.001 